\title{
MENYOAL KONEKSITAS KRITIK HADITS IGNAZ GOLDZIHER DAN JOSEPH SCHACHT
}

\author{
Muhammad Ulul Albab \\ Fakultas Ushuluddin UIN Sunan Ampel Surabaya \\ ulul.edu@gmail.com
}

\begin{abstract}
This article discusses the role of orientalists in looking at the hadith of the Prophet Mubammad $S A W$ with their views. Orientalist purposes and objectives certainly have a special mission in shaking the grip of Muslims, namely hadith. Orientalist figures often consider the teachings of Islam because of the nature of his hatred which is a legacy of defeat on the war of Christian side. So came the names of orientalists with a high mentality in the fight against Islam. One of them is Ignaz. Goldziher and Joseph Schacht who are active in criticizing hadiths. Both have deep connections in having the same view regarding the authenticity of hadith. So it is necessary to review the direction of their criticism to be able to find a descriptive analysis in refusing it. Therefore, the two orientalist figures have a close relationship in his view of the badith, so that we as Muslims certainly bave an obligation in clarifying the authenticity of hadith and the science correct of sanad.
\end{abstract}

Keywords: Hadith, Ignaz, Goldziher, Joseph Schacht

\begin{abstract}
Abstrak
Artikel ini membahas tentang peran orientalis dalam memandang hadits Nabi Muhammad SAW dengan kacamata mereka. Maksud dan tujuan orientalis tentu mempunyai misi khusus dalam menggoyahkan pegangan umat Islam, yaitu hadits. Sosok orientalis seringkali menganggap rendah ajaran Islam lantaran dari sifat kebenciannya yang merupakan warisan akibat kekalahan di pihak Kristen dalam perang salib. Sehingga muncul nama-nama orientalis dengan mentalitas tinggi dalam memerangi Islam. Salah satunya adalah Ignaz Goldziher dan Joseph Schacht yang aktif dalam mengkritik hadits. Keduanya mempunyai koneksitas dalam dalam mempunyai pandangan sama terkait otentitas hadits. Sehingga perlu tinjauan ulang arah kritik mereka untuk bisa menemukan analisa diskriptif dalam membantahnya. Oleh karenanya, kedua tokoh orientalis tersebut mempunyai hubungan erat dalam pandangannya terhadap hadits, sehingga kita sebagai Muslim tentu mempunyai kewajiban dalam memperjelas terkait otentitas hadits dan ilmu sanad yang benar.
\end{abstract}

Kata Kunci : Hadits, Ignaz Goldziher, Joseph Schacht 



\section{Pendahuluan}

Orientalisme berasal dari kata Perancis orient yang berarti Timur dan isme yang berarti aliran, paham, ilmu, keyakinan, dan sistem. ${ }^{1}$ Jadi, orientalisme merupakan suatu studi yang dilakukan oleh orang-orang Barat (selain Timur) untuk mempelajari situasi Timur, khususnya hal-hal yang berhubungan dengan sejarah, agama, bahasa, etika, seni, tradisi, serta adat kebiasaanya ${ }^{2}$. Orientalisme adalah suatu warna perang dingin yang dilancarkan oleh bangsa Eropa guna memperdaya Islam dan umatnya. Gencaran itu dilakukan setelah mereka kalah dan gagal dalam perang salib kala itu.

Para orientalis memulai kajian terhadap Islam sejak abad 19 Masehi. $^{3}$ Hal ini disebabkan efek keberadaan Nabi saat itu menjadi momok sentral dalam kehidupan orang-orang Nasrani yang juga memikirkan kemajuan golongan dan pemahamannya. Terutama sebuah hukum yang dinamakan hadits. Orang Islam dan sekitarnya lebih menerima aturan dan pedoman (hadits) yang ditawarkan oleh Nabi. Atas dasar itu juga lah mulai muncul banyak musuh-musuh Islam

1 Idri, Hadis dan Orientalis: Perspektif Ulama Hadis dan Orientalis Tentang Hadis Nabi (Depok: Kencana, 2017), 1.

2 Ahmad, Ibrahim Khalil, Siasat Misi Kristen dan Orientalis, Terj. Zeyd Aly Amar (Jakarta: Gema Insani Press, 1986), 23.

3 Arif, Syamsuddin, Orientalis \& Diabolisme Pemikiran Gema Insani, 2008), 47-48. yang berusaha untuk merobohkan dan mempengaruhi ajaran kepercayaan Muslim dalam hadits tersebut.

Kemunculan musuh-musuh Islam khususnya dalam kajian hadits yang dipelopori orientalis tersebut menjadi contoh era baru di mana perang sudah tidak menggunakan fisik. Akan tetapi mulai menggunakan asupan pemikiran dan kajian yang mampu mempengaruhi keyakinan. Namun belum diketahui secara jelas siapa tokoh orientalis pertama yang memulai kajian terhadap Islam. Sehingga didapati para ahli pun mempunyai banyak pendapat yang berbeda terkait itu. Ada yang berpendapat bahwa yang memuai pertama adalah dari kalangan sarjana Barat, yaitu Alois Sprenger. Kemudian diikuti Sir Willian Muir dalam karyanya Life of Muhamet, dan disempurnakan dalam karya puncaknya oleh Ignaz Goldziher. ${ }^{4}$ Sejatinya para sarjana Muslim pun banyak tahu tentang kontroversi Ignaz Goldziher tersebut. Salah satu penyebab tersebarnya isu otentisitas hadits mulai diragukan juga atas kajian Ignaz.

Sejak saat itu juga mulai tumbuh generasi-generasi berikutnya yang berusaha menyerang pegangan umat Islam dalam kajian hadits. Antara lain: Cristian Snouck Hurgronje (1857-1936), Hamilton Alexander

4 Idri, Studi Hadis (Jakarta: Prenada Media Group, 2016), 307. 


\section{Muhammad Ulul Albab}

Roskeen Gibb (1895-1971), Joseph Schacht (1902-1969), GHA Joynboll, Bernard G. Weiss, Arberry, Jeffre, dan masih banyak yang lainnya. ${ }^{5}$ Selain Ignaz Goldziher, Nama Joseph Schacht dengan karyanya The Origin of Mubammadan Jurisprudence akan menjadi fokus pembahasan penulis. Hal itu dikarenakan Ignaz juga berhasil menanamkan bumbu keraguan terhadap hadits, sehingga perlu ada pengkajian koneksitas kritik kedua tokoh orientalis tersebut.

\section{Pembahasan}

\section{Biografi Singkat}

Tokoh pemikiran orientalis yang akan dibahas pada penelitian ini yang sekaligus mewakili beberapa pandangan Barat tentang hadits Nabi Muhammad SAW, antara lain:

\section{Ignaz Goldziher}

Sebagai keturunan Yahudi dari keluarga terpandang, Ignaz Goldziher lahir di Hongari pada tanggal 22 Juni $1850^{6}$ dengan memiliki pengaruh besar bagi masyarakat sekitarnya. Kecerdasan dan ketekunannya menjadikan dirinya mahir dalam membaca Bible dalam bahasa Ibrani sejak umur lima tahun. Bahkan, masih tergolong mudah bagi anak sejawatnya untuk mampu membuat karya dan mempublikasikannya tentang doadoa Ibrani dan asal usulnya. ${ }^{7}$ Kemudian ia

\footnotetext{
${ }^{5}$ Idri, Studi Hadis, 307.

${ }^{6}$ Ignaz Goldziher, Pengantar Teologi dan Hukum Islam, terj. Hesri Setiawan (Jakarta: INIS, 1991), 3.

7 Cucu Setiawati, "Kajian Orientalis Ignaz Goldziher Tentang Hadits dan Sunnah", Journal of Qur'̄̄n and Hadith Studies', 7. 2 (2018): 4.
}

memulai pendidikannya di Universitas Budapest dan dilanjukan lagi ke Universitas Leipzig, Jerman. Atas keseriusannya di bawah bimbingan Profesor Orientalisme, Flesser, ia meraih gelar Doctor pada tahun 1870 dengan karya "Penafsir Taurat yang Berasal dari Tokoh Yahudi Abad Tengah".

Tepatnya pada tahun 1872, Goldziher berkesempatan mendapatkan tugas selama satu tahun di Cairo, Suriah, dan Palestina untuk memperdalam ilmu Timur Tengah. Universitas al-Azhar menjadi salah satu tempat pengembangan pengetahuannya dalam studi ilmu Islam. Sesekali Goldziher juga menyempatkan waktunya ke Palestina dan Mesir untuk membandingkan keilmuannya. Sehingga sangat jelas akan ketekunan Goldziher dalam mencoba memahami apa yang menjadi kajian orang Timur.

Setelah selesai ekspedisinya ke beberapa Negara Timur, Glodziher memutuskan untuk kembali ke kampung halamannya Hongaria untuk menekankan pentingnya kajian peradaban Arab (Islam). Kemudian dirinya dinobatkan sebagai Profesor studi bahasa saat itu. Dengan karya-karyanya dalam membahas Islam pun turut ia kembangkan dan disebar luaskan dengan berbagai bahasa, salah satunya bahasa Jerman. Sebab pemikiran dan kritiknya akan Islam, ia menjadi sangat terkenal dan ber-

8 Inama Anusantari, "Perspektif Orientalis Dalam Mengkaji Hadits Dan Bantahan Kaum Muslim: Perspektif Ignaz Goldziher, Joseph Franz Schacht Dan Mustafa Azami," Riwayah: Jurnal Studi Hadis (2020): 113. 
pengaruh terhadap tokoh orientalis lain hingga meninggalnya di umur 71 (13 November 1921). ${ }^{9}$

\section{Joseph Schacht}

Orientalis hadits dengan nama lengkap Pof. Dr. Joseph Schacht adalah tokoh penting yang sedikit banyak dipengaruhi oleh Ignaz Goldziher. Schacht lahir di Silisie Jerman pada tanggal 15 Maret 1902 M. Awal mulai dirinya menjadi orientalis sejak belajar psikologi, theology, dan bahasa ketimuran di Universitas Leipzig. Saat itu masih terbilang muda (21) ketika dirinya mendapatkan gelar Doktor dalam studinya di Universitas Berslauw pada tahun 1923.

Karir Schacht sangat cepat mengingat pada tahun 1925 sudah menjadi dosen di Universitas Fribourg dan dikukuhkan gelar profesornya pada tahun 1929. Seperti halnya Goldziher, ia juga menjajaki dunia Timur Tengah di Universitas Cairo Mesir sebagai Guru Besar. ${ }^{10}$ Setelah beberapa tahun mengajar di Mesir, perang dunia II membuat Schacht memutuskan untuk pergi dan berpindah ke Inggris untuk bekerja di radio BBC London. Sejak saat itu Schacht menemukan kehidupannya yang baik untuk menetap lebih lama di Inggris. Sampai ia pun

\footnotetext{
9 Inama Anusantari, "Perspektif Orientalis Dalam Mengkaji Hadits Dan Bantahan Kaum Muslim: Perspektif Ignaz. Goldziher, Joseph Franz. Schacht Dan Mustafa Arami", 113.

10 Ali Mustafa Yaqub, Kritik Hadis (Jakarta: Pustaka Firdaus, 1995), 19.
}

juga menikah dengan wanita Inggris. Schacht memutuskan untuk menjadi warga Inggris pada tahun 1947.

Sesaat setelah beberapa tahun Schacht menjalani pekerjaannya yang tidak lain untuk Inggris, akhirnya ia melapaskannya dan pindah ke Belanda pada tahun 1954. Dari sini, sosok yang mempunyai nama lengkap Joseph Franz Schacht tersebut memulai mempublikasi karya-karya hasil cetakannya, seperti buku Dairah al-Ma'arif al-Islamiyah. ${ }^{11}$ Selain Schacht ahli dalam ilmu teologi, sejarah, dan manuskrip-manuskrip Arab, dirinya juga pakar dalam ilmu figh. Sehingga dirinya berhasil menorehkan sebuah karya buku monumental yang berjudul The Origins Of Muhammadan Jurisprudence. ${ }^{12}$ Schacht dalam buku tersebut mampu memahami perkembangan hukum Islam yang banyak dipegang oleh umat Muslim. Khususnya pada kajian pemikiran Imam Syafi'i.

Schacht meninggal saat menjadi Guru Besar di Universitas New York pada tahun 1969. ${ }^{13}$ Pola fokus kajian Schacht menjadi sangat kontroversial bagi umat Islam dalam memahami hukum. Awal mula perkembangan hukum hingga anggapan hadits ada-

11 Munandar, "Sanggahan Atas Teori Ingkar As-Sunnah Joseph Schacht", Shabib: Jurnal Kewabyuan Islam, $\quad 1.1 \quad$ (2017): 46-57. <http://jurnal.uinsu.ac.id/index.php/shahih/article/ view/1897/1522>.

12 A. Badawi, Ensiklopedi Tokoh Orientalis (Yogyakarta: LKiS 2003), 366.

${ }^{13}$ A. Badawi, Ensiklopedi Tokoh Orientalis, 364. 
lah bukan sumber hukum utama, menjadikan Schacht sebagai orientalis yang berbahaya. Hingga sekarang, pemikiran yang dituangkan pada karya-karyanya soal Islam masih sering dikaji. Khususnya dalam sejarah hukum Islam.

\section{Koneksitas Kritik Pada Hadits}

Ignaz Goldziher secara tegas membantah otentisitas hadits yang bersumber dari Nabi Muhammad. Dalam hal itu, Goldziher turut membedakan antara hadits dan sunnah sesuai dengan pemikiran orientalis. Secara garis besar, Goldziher menyimpulkan bahwa hadits adalah akibat dari pertumbuhan dan perkembangan Islam secara sosial dan historis selama dua abad pertama. ${ }^{14}$ Sedangkan sunnah menurutnya adalah peraturan-peraturan praktis yang muncul sebab kebiasaan-kebiasaan umat Islam saat itu di ranah ibadah ataupun hukum. ${ }^{15}$

Tokoh yang banyak dikenal dengan sebutan bapak orientalis tersebut sangat serius dalam menelaah hadits-hadits Nabi yang digunakan sebagai pijakan kedua umat Islam setelah Al-Qur'an. Dalam kritiknya, Goldziher menggunakan metode filologi dan disertai kritik historis di dalamnya, yang mana ia tuangkan dalam sebuah buku dengan judul Mubammedanische Studien (Studi Pengi-

14 Syarifuddin and Moh Zaiful Rosyid, "Persoalan Otentitas Hadis Perspektif Ignaz Golziher", Al-Qalam: Jurnal Ilmiah Keagamaan Dan Kemasyarakatan, $\quad 3.2 \quad$ (2019): 193. <https://doi.org/10.35931/aq.v3i2.158>

${ }^{15}$ Idri, Studi Hadis, 312. kut Muhammad). ${ }^{16}$ Ia juga melancarkan kritik terhadap kitab Sabih al-Bukhari yang sampai sekarang menjadi rujukan umat Islam. Ia menyatakan bahwa kitab Sabih alBukhari terdapat hadits tidak sahih dikarenakan itu karya generasi sahabat dan tabi'in. Tidak otentik berasal dari Nabi Muhammad SAW.

Goldziher juga menawarkan metode kritik baru yaitu kritik pada matan. Menurutnya kritik matan hadis itu mencakup berbagai aspek seperti politik, sains, sosio kultural dan lain sebagainya. Goldziher menyatakan hadis yang terdapat dalam kitab Sabih al-Bukhari hanya melalui proses kritik sanad dan tidak melalui kritik matan. Setelah adanya kritik matan yang dilakukan oleh Goldziher, hadis tersebut dinyatakan palsu karena merupakan produk kreasi kaum muslimin belakangan, karena kodifikasi hadis baru terjadi beberapa abad setelah Nabi Muhammad SAW wafat. ${ }^{17}$

Dengan teori tersebut, Goldziher menyimpulkan pandangannya pada hadits sebagai berikut: pertama, hadits adalah hasil perkembangan Islam melalui situasi sosial. Kedua, terdapat peran sahabat dan tabi'in dalam memalsukan hadits. Ketiga, rentang waktu antara Nabi Muhammad SAW dengan tokoh-tokoh penghimpun hadits sangat

16 Siska Helma Hera, "Kritik Ignaz Goldziher Dan Pembelaan Musthofa Al Azami Terhadap Hadis Dalam Kitab Shahih Al-Bukhari", Jurnal Living Hadis, 5.1 (2020): 133.

17 Siska Helma Hera, "Kritik Ignaz Goldziher Dan Pembelaan Musthofa Al Azami Terhadap Hadis Dalam Kitab Shahih Al-Bukhari", 141. 
rentan ada kepentingan aliran masingmasing. Keempat, ia beranggapan bahwa enam kitab ${ }^{18}$ hadits yang menjadi pegangan umat Islam adalah salah satu usaha ulama menghimpun hadits yang tercecer dan dinilai sebagai hadits sahih. ${ }^{19}$

Hal itu senada dengan gagasan teori Joseph Schacht terkait hadits yang digunakan umat Islam adalah bukan dari Nabi. Ia mengambil dari sisi hukum yang mana menurutnya adalah hanya proyek ulama yang mencoba menyandarkan nama Nabi $\mathrm{Mu}-$ hammad SAW. Schacht mengakui bahwa pemikirannya dalam mengkritik hadits itu sejalan dengan apa yang dipikirkan pendahulunya, yaitu Ignaz Goldziher. Dengan rasa kagumnya pada Goldziher, Schacht juga menyampaikan pidato ilmiahnya yang berbicara soal Islam yang berjudul $A$ revolution of Islamic Tradition". ${ }^{20}$ Terdapat dua buku lagi karya Schacht yang diakui sebagai "kitab suci" orientalis yang sangat monumental.

18 (1). Shabih Bukhari; Imam Bukhari, (2). Shahih Muslim; Imam Muslim, (3). Sunan an-Nasa' 7 ; Imam Nasa'i, (4). Sunan Abu Dawud; Imam Abu Dawud, (5). Sunan at-Tirmidri; Imam Tirmidzi, (6). Sunan Ibnu Majab; Imam Ibn Majah.

19 Syarifuddin and Moh Zaiful Rosyid, "Persoalan Otentitas Hadis Perspektif Ignaz Golziher", 8

20 Salah satu kalimat pidatonya : "One of these fondation, I may take it for granted, is Goldziher's discovery that the traditions from the prophet and from his companions do not contain more or less authentic information on the earliest period of Islam to which they claim to belong, but reflect opinions held during the first two and half centuries after tha hijra", lihat di : Setyawan, "Studi Hadits: Analisis Terhadap Pemikiran Schacht dan'Azami”, Jurnal Kajian Islam Interdisipliner, I (2), 253.
Antara lain, "The Origin of Mubammadan Jurisprudence" dan "Introduction to Islamic Law". Pembahasan dua buku tersebut tidak lain berisi gagasan-gagasan Schacht mengkritik otentisitas atau keaslian hadits. Hal itu membuktikan adanya koneksitas antara Ignaz Goldziher dengan Joseph Schacht dalam menilai hadits.

Dasar kritik yang digunakan Schacht dalam memulai gagasannya lantaran pemahamannya dalam melihat sistem isnad yang periwayatannya mengarah ke belakang sampai ke Nabi SAW. Menurutnya hal seperti itu sangat rentan dalam masuknya hadits-hadits palsu di masa tabi'in. Adapun ringkasan permasalahan terkait isnad menurut Schacht adalah: ${ }^{21}$

1) Sistem isnad dimulai pada awal abad kedua (masa tabi'in).

2) banyak isnad yang diletakkan sembarangan oleh para tabi'in yang berkeinginan haditsnya diproyeksikan ke belakang.

3) Melengkapi beberapa isnad yang dulunya tidak lengkap.

4) Karya Imam Syafi'i yang diakui keshahihannya merupakan himpunan hadits-hadits yang dilacak ke belakang

21 Munandar, "Sanggahan Atas Teori Ingkar As-Sunnah Joseph Schacht", Shabih: Jurnal Kewabyuan Islam, $\quad 1.1 \quad$ (2017): 46-57. $<$ http://jurnal.uinsu.ac.id/index.php/shahih/article/ view/1897/1522>. 


\section{Muhammad Ulul Albab}

sampai kepada satu sumber. "Isnadisnad keluarga" adalah palsu, dan demikian pula materi yang disampaikan di dalam isnad-isnad itu.

5) Terdapat beberapa comman narrator dalam rantai periwayatan

Dari lima asumsi Schacht di atas, Schacht menjelaskan lebih rinci dengan sebuah teorinya untuk mendukung kerangka tersebut. Ada teori matang Schacht yang digunakan untuk menyerang otentisitas hadits dari sisi sanad adalah projecting back.

Penjelasan tentang teori ini berbicara terkait keaslian hadits yang direkonstruksikan melalui hubungan sejarah antara hukum Islam dengan hadits Nabi SAW. Mengaca dari sejarah yang ada, Schacht menegaskan bahwa hukum Islam belum eksis pada masa al-Sya'bi' ${ }^{22}(110 \mathrm{H})$. Hal itu menggambarkan munculnya hadits-hadits Nabi adalah buatan orang setelah masa al-Sya'bi. Oleh karena itu Schacht berpendapat bahwa munculnya hukum Islam dimulai pada masa adanya pengangkatan para qadhi (hakim agama). Pada masa shahabat (kbulafa al-rasyidin) masih belum ada gejolak hadits. ${ }^{23}$

Schacht memahami sejarah kemunculan hadits yang dimulai di masa qadhi. Maksud dari teori projecting back tidak lain adalah

22 Al-Sya'bi adalah Tabi'in terkemuka yang lahir pada pemerintahan Umar bin Khatab $(17 \mathrm{H})$. Ia seorang imam ilmu, penghafal hadits, dan ahli hukum (figh). Lihat di; Moenawar Chalil, Biografi Empat Serangkai Imam Madzab Hanafi, Maliki, Syafi'i, Hambali (Jakarta: Bulan Bintang, 1995), 19.

${ }^{23}$ Joseph Schacht, An Introductionti Islamic Law (Oxford: Clarendom Press, 1964), 34. bagaimana pendapat para qadhi tersebut dinisbatkan pada orang terdahulu yang dekat dengan Nabi. Sehingga sebuah hadits mendapatkan legitimasi yang lebih kuat dan meyakinkan bahwa pendapat tersebut datangnya dari hadits Nabi SAW.

Gagasan yang dibangun Schacht dengan teori projecting back-nya tentu senada dengan apa yang digagas dengan Ignaz Goldziher. Teori yang mengklaim bahwa sanad lengkap yang disandarkan pada otoritas yang kuat dan berujung ke Nabi $\mathrm{Mu}-$ hammad adalah ciptaan para fuqaha'. Pada sisi lain juga ada yang mempunyai keinginan memperkokoh madzab mereka yang ingin dicap sebagai salah satu periwayat hadits yang handal. Hal yang dilihat oleh Schacht terhadap hadits adalah dari sisi historis. Sehingga terlihat jelas Schacht membentuk koneksitas kritiknya bersama pendahulunya Ignaz, yang mana menyebutkan bahwa hadits itu tidak otentik (asli) dari Nabi Muham$\operatorname{mad}$ SAW.

\section{Analisis dan Bantahannya}

Dalam penelitian ini, penulis menganalisis gagasan konesksitas kritik Ignaz dan Schacht terhadap hadits sangat menonjol kebenciannya terhadap Islam. Ciri orientalis tersebut tergolong dalam kategori "Misionaris Tradisional". Gagasan dan pemikirannya tidak lain untuk sebuah misi kepentingan golongan atau agama. Koneksitas yang dibangun hanya untuk merobohkan 
keyakinan umat Islam dalam berpedoman, khususnya pada hadits.

Orientalis sering kali memandang bahwa hadits adalah hasil karya pemikir atau para ahli fiqh yang ingin menjadikan Islam sebagai agama multidimensional. ${ }^{24} \mathrm{Hal}$ itu sesuai apa yang menjadi gagasan Ignaz Goldziher dan Joseph Schacht tentang hadits yang bukan bersumber dari Nabi $\mathrm{Mu}-$ hammad. Kedua tokoh utama tersebut memahami dari satu sisi saja untuk disesuaikan koneksitas kritiknya bahwa hadits lahir pada abad pertama dan kedua hijriyah dengan ditandai majunya Islam.

Penulis membantah terkait metode yang digunakan oleh Orientalis Ignaz dan Schacht masih sangat mentah. Metodologi historis yang digunakannya masih sangat tidak cukup dalam menilai otentisitas hadits. Hal itu dikarenakan kemunculan hadits hingga kodifikasinya yang dirancang oleh para ulama sesungguhnya tidak berangkat dari ruang kosong. Ulama membangun keutuhan hadits yakni berangkat dari penelusuran, pengidentifikasian, hingga penyeleksian. Sudah berabad-abad lamanya untuk memikirkan sebuah kaedah, istilah, konsep, atau bahkan teori yang mampu dijadikan pegangan dalam menentukan benar

24 Syarifuddin and Moh Zaiful Rosyid, "Persoalan Otentitas Hadis Perspektif Ignaz Golziher", 310. tidaknya sebuah hadits. Alhasil ketika orientalis melancarkan kritiknya terhadap para penjaga hadits (kitab Shabih Bukhari) justru membuat kajian kitab hadits tersebut mendapatkan kedudukan yang lebih terhormat. Sehingga di era berikutnya akan ada sarjana-sarjana yang mencoba menelaah kembali (mensyarah) kitab tersebut yang mana akan menjadi luas dan akurat pembahasannya. ${ }^{25}$

\section{Penutup}

Pembahasan penting terkait koneksitas kritik orientalis ini mendorong sarjana atau peneliti Muslim untuk bisa skeptis dalam melihat pengetahuan. Mengaca dari gerakan skeptis orientalis yang mampu membangun teori dan gagasannya untuk merobohkan Islam menjadi bukti bahwa sudut pandang bisa dilihat dari sisi manapun. Kritik sanad dan matan hadits yang dilancarkan oleh $\mathrm{Ig}$ naz adalah sebuah kode untuk umat Islam agar lebih matang dalam menjaga otentisitas hadits. Begitu juga teori projecting back yang dibangun Schacht perlu ditanggapi lebih serius dalam menyangkalnya. Para Ulama sudah membekali Ulum al-Hadits untuk bisa membantah terkait anggapan proyeksi ke belakang tersebut bukan sewenang-wenang dalam urusan penisbatan.

25 Siska Helma Hera, "Kritik Ignaz Goldziher Dan Pembelaan Musthofa Al Azami Terhadap Hadis dalam Kitab Shahih Al-Bukhari”, 146. 


\section{Muhammad Ulul Albab}

\section{Daftar Pustaka}

Ahmad, Ibrahim Khalil. Siasat Misi Kristen dan Orientalis, Terj. Zeyd Aly Amar. Jakarta: Gema Insani Press, 1986.

Arif, Syamsuddin. Orientalis \& diabolisme pemikiran. Gema Insani, 2008.

Badawi, A. Ensiklopedi Tokoh Orientalis. Yogyakarta: LKiS, 2003.

Goldziher, Ignaz. Pengantar Teologi dan Hukum Islam, terj. Hesri Setiawan Jakarta: INIS, 1991.

Idri. Hadis dan Orientalis: Perspektif Ulama Hadis dan Orientalis Tentang Hadis Nabi. Depok: Kencana, 2017. Studi Hadis. Jakarta: Prenada Media Group, 2016).

Moenawar Chalil. Biografi Empat Serangkai Imam Madzab Hanafi, Maliki, Syafi'i, Hambali. Jakarta: Bulan Bintang, 1995. Schacht, Joseph. An Introductionti Islamic Law. Oxford: Clarendom Press, 1964.

Yaqub, Ali Mustafa. Kritik Hadis. Jakarta: Pustaka Firdaus, 1995.

Anusantari, Imama. "Perspektif Orientalis Dalam Mengkaji Hadits Dan Bantahan Kaum Muslim: Perspektif Ignaz Goldziher, Joseph Franz Schacht Dan Mustafa Azami". Riwayah: Jumal Studi Hadis (2020).

Munandar, "Sanggahan Atas Teori Ingkar As-Sunnah Joseph Schacht", Shabib: Jurnal Kewabyuan Islam, 1.1 (2017).
Setiawati, Cucu. "Kajian Orientalis Ignaz Goldziher Tentang Hadits dan Sunnah," Journal of Qur'̄̄n and Hadith Studies', 7. 2 (2018).

Setyawan, "Studi Hadits: Analisis Terhadap Pemikiran Schacht dan 'Azami', Jurnal Kajian Islam Interdisipliner, I (2).

Siska Helma Hera, "Kritik Ignaz Goldziher Dan Pembelaan Musthofa Al Azami Terhadap Hadis Dalam Kitab Shahih Al-Bukhari", Jurnal Living Hadis, 5.1 (2020).

Syarifuddin and Moh Zaiful Rosyid, "Persoalan Otentitas Hadis Perspektif Ignaz Golziher", Al-Qalam: Jurnal Ilmiah Keagamaan Dan Kemasyarakatan, 3. 2 (2019). 